\title{
Investigating the Effect of Financial Development on Output Growth Using the ARDL Bounds Testing Approach
}

\author{
Abdullah M. Al-Malki ${ }^{1} \&$ Ghazi I. Al-Assaf ${ }^{2}$ \\ ${ }^{1}$ Administrative Sciences Department, King Saud University, Riyadh, KSA \\ ${ }^{2}$ Business Economics Department, The University of Jordan, Amman, Jordan \\ Correspondence: Ghazi I. Al-Assaf, Business Economics Department, The University of Jordan, Amman, Jordan. \\ E-mail: g.alassaf@ju.edu.jo
}

Received: April 19, 2014

Accepted: July 11, 2014

Online Published: August 25, 2014

doi:10.5539/ijef.v6n9p136

URL: http://dx.doi.org/10.5539/ijef.v6n9p136

\begin{abstract}
The linkage between financial development indicators and output growth is a debatable issue. However, it is believed that financial development is essential for maintaining a high rate of economic growth. This paper explores the dynamic relationship between financial development and economic growth, using time series data from Saudi Arabia over the period 1970 to 2008. Unlike the majority of previous studies, we employ the ARDL bounds testing approach proposed by Pesaran et al. (2001). Also Granger causality tests were performed within a VECM framework. Three indicators are selected to represent financial development, namely credit to private sector as a ratio of nominal GDP, bank deposit liabilities as a ratio of GDP, and financial savings as a ratio of GDP. The results of the ARDL bounds test indicate that a long-run relationship among the variables exists, where economic growth is found to be significantly influenced by financial development indicators. In addition, Granger causality test shows that developing countries have a supply-leading causality pattern of development rather than a demand-following one.
\end{abstract}

Keywords: financial development, economic growth, bounds testing, ARDL, co-integration, causality, Saudi Arabia

\section{Introduction}

The relationship between financial development and the real economy has received considerable interest in recent theoretical and empirical studies. The theoretical underpinnings of this relationship can be found in the works of Bagehot (1873) and Schumpeter (1954) (first edition in 1911) (Note 1) and more recently in the works of Gurley and Shaw (1955, 1960), McKinnon (1973), Shaw (1973) and Lucas (1988). Theory provides conflicting views on the effect of financial development on economic growth. Most empirical studies, that derive their motivation from these theoretical approaches, suggested by several economic schools of thought, may be divided into three categories. First, the structuralists claimed that the quantity and composition of financial variables stimulates economic growth by directly increasing savings in the form of financial assets, as a result encouraging capital accumulation and therefore, economic growth. Second, the repressionists, the financial repressionists, often referred to as followers of the "Mckinnon-Shaw" hypothesis, as proposed by McKinnon (1973), Shaw (1973) and Fry (1978), stated that financial liberalization in the form of a suitable rate of return on real cash balances is a vehicle of encouraging economic growth. The crucial idea of this hypothesis is that a more liberalized financial system will stimulate an increase in savings and investment and, as a result, promote economic growth. Third, the endogenous growth theory supporters arrive at similar conclusions to the McKinnon-Shaw hypothesis by explicitly modeling the services provided by financial intermediaries, such as risk-sharing and liquidity provision (see Vazakidis \& Adamopoulos, 2009).

The relationship between financial development and economic growth has been investigated empirically by authors in the literature such as Gupta (1984), Jung (1986), King and Levine (1993 a, b), Murinde and Eng (1994), De Gregorio and Guidotti (1995), Demetriades and Hussein (1996), Rousseau and Wachtel (2001) and Khan and Senhadji (2000) among others. The huge and growing literature in this issue can be summarized under two major trends. On the one hand, cross country and panel data studies discover a positive effect of financial development on output growth. On the other hand, the majority of time series studies discover either unidirectional causality from finance to growth or bi-directional causality, Kar et al. (2010). 
More recent empirical studies find a positive and significant relationship between financial development and economic growth; see Seetanah (2008) and Odhiambo (2010) among others. Seetanah (2008) examines the dynamic empirical relationship between financial development and economic growth performance for the case of the developing island state of Mauritius over the span 1952-2004, employing two different measures for financial development in an ARDL approach. The results indicate that financial development has been contributing to economic growth in both the short and long run. Odhiambo (2010) investigates the dynamic causal relationship between financial development, investment and economic growth using three indicators for financial development in an ARDL framework. The results reveal that, on the whole, economic growth has extensive influence on the financial sector development. The study also finds that there is a distinct unidirectional causality from economic growth to investment, and that investment Granger causes financial development.

Studies using time series techniques for developing countries have been scarce and to our knowledge only a few studies have been conducted for the case of Arab countries. The purpose of this paper is to examine the empirical link between financial development and economic growth in Saudi Arabia, using time series data over the period 1970-2008. The structure of the paper is as follows. Section 2 presents the models and discusses variables and data sources. Section 3 describes the methodology used. Section 4 provides the empirical results. Finally, Section 5 concludes.

\section{Methodology}

\subsection{Variables}

\subsubsection{Financial Development Indicators}

The choice of variables to represent the level of financial services created in an economy, and how to assess the extent and efficiency of financial intermediation, are the main difficulties in an empirical study of this nature. Financial development is usually defined as a process that marks development in the quantity, quality, and efficiency of financial intermediary services. This procedure engages the relations of many activities and institutions. As a result, it cannot be captured by a single measure. Some researchers such as Hussein (1999) and Ang and Mckibbin (2007) state that the development of the financial sector has many dimensions and, therefore, there is no single variable that can capture all aspects of financial development see also Abu-Bader and Abu-Qarn (2008):

"In the literature on the interaction between growth and financial development, the problem of measuring financial development is a difficult one" see Saci and Holden (2008), p. 1549.

Several indicators of financial development have been suggested in the literature and different variables will measure different aspects of the financial system. Three types of indicators are applied to examine the relationship between financial development and economic growth in the empirical analysis of this paper.

The standard measure of financial development, utilized in the literature, is the ratio of broad money, usually M2, to nominal GDP (World Bank Report, 1989). Nevertheless, this ratio measures the extent of monetisation rather than financial depth. In developing countries, monetisation may be increasing without financial development; therefore, it is not an entirely satisfactory indicator of financial depth. We therefore, follow authors in literature, such as Demetriades and Hussein (1996), Khan et al. (2005), Boulila and Trabelsi (2002) and Trabelsi (2002) among others and define financial depth as the ratio of total bank deposit liabilities to nominal GDP. The ratio of liquid liabilities to GDP aims to measure the overall size of the financial intermediary sector. It shows the level of the liquidity provided to the economy. However, it does not reflect the allocation of savings and so cannot be an accurate index of the activities of financial intermediaries. Liquid liabilities may therefore be calculated as currency plus the demand interest-bearing liabilities of financial intermediaries and non-bank intermeddlers, divided by GDP. This indicator used by King and Levine (1993a), Rousseau and Watchtel (2000) and Levine et al. (2000), see Saci and Holden (2008).

In the case of Saudi Arabia, currency held outside banks comprised of approximately 45 percent of M2 on average, for the period 1963-1975. Nevertheless, this rate has decreased gradually, since then, and become less than 20 percent after 2000. Consequently, we select bank deposits liabilities (M3-currency in outside banks over GDP) as a ratio of GDP (Bdr), to provide our first measure of financial development because of the upward trend in financial innovation in the financial system. This ratio is a measure of the size of the banking sector in relation to the economy as a whole. An increase in this ratio can be explained as a development in financial deepening in the economy see Garcia and Liu (1999), Boulilah and Trabelsi (2004) and Neceur et al. (2007).

Recent studies by King and Levine (1993, a, b), Levine and Zervos (1998), Rousseau and Wachtel (2000) and 
Chaudhuri and Smiles (2004) used this variable to measure the impact of financial sector on economic growth, and other studies used this variable as a measure of financial deepening (Note 2). On the other hand, some researches, e.g Sbeiti (2006) and Liang and Teng (2006), use the variable 'bank deposits' (demand and time savings deposits) instead of liquidity liabilities, as defined above, or money supply over GDP.

We use private domestic credit provided by the banking system as a ratio of GDP as a second measure of financial development to account for financial intermediary development. This ratio is a measure of the role of financial intermediaries in provision of longer-term financing of investment projects by the private corporations. This variable also gives information about commercial banks, credit allocated to private sector, as compared the size of the economy as a whole, and finally, it is a measure of the level of prevision of financial services, see Naceur et al. (2007) and Nili and Rastad (2007). In addition, Emmanual (1997) declares that credit to private sector is responsible for the quantity and quality of investment and, in turn, for economic growth. Higher levels of this ratio are clarified as indicating lower transaction costs and higher levels of financial services and therefore greater financial intermediary development. Levine (1997) finds a positive relationship between real GDP per capita and the ratio of gross claims on the private sector to GDP.

The third measure of financial intermediaries development is the ratio of financial savings to GDP, where financial savings are calculated by the difference between M3 and M1 (FS=M3-M1) (Note 3). This measure is used to consider the structure of the financial system and determine the significance of its different elements. The ratio of financial savings to GDP can reveal an improvement in bank deposits and/or other financial resources outside the banking sector, which are probably to be used for accumulation and growth. It is supposed to be positively associated with growth, if savings deposits increase, compared to payments transactions, the financial system develops, see Outreville (1999), Boulila and Trabelsi (2004) and Saci and Holden (2008).

\subsubsection{Economic Growth Indicator}

Albatel (2003, pp. 9-10) argues that even though the real gross domestic product (GDP) is a good indicators of the overall level of economic development and activity in any economy, it could nevertheless be argued that, for Saudi Arabia, this variables does not accurately reflect the level of economic activity within the economy. This is attributed to the economy's reduced ability to influence oil production levels and the price of oil in international markets. With the extraction and export of oil production being the dominant component of GDP, and government revenue, a large part, the economic activity within the country is determined outside its system and has very little control over it.

We have used non-oil real GDP per capita in Saudi Riyals (SR) as the dependent variable but the results were not satisfactory. Consequently, we utilize per capita real GDP to measure economic growth. The variable of economic activity is real GDP per capita (Y), expressed in constant prices $(1999=100)$. As income grows, its cyclical component should have a positive occurrence on the size of the stock market. Moreover, higher income denotes better education, better business environment and more wealthy citizens. We expect a positive effect between per capita real GDP and financial development indicators, investment, and trade openness, see Naceur et al. (2007). In addition, following Edwards (1992) and Onafowora and Owoye (1998), among others, we also incorporate two control variables, namely investment as a ratio of GDP and Openness, and the ratio of domestic investment to GDP (INV/GDP) as a measure of physical capital. Domestic investment is measured by the gross fixed capital formation. It is expected that investment has a positive effect on GDP, while trade openness is calculated as total exports plus total imports over GDP.

It is supposed that these variables could also have an impact on economic growth. The omission of these variables could therefore bias the direction of causality between financial development and economic growth. In view of this, we employ two these control variables, investment as a percentage of GDP (INVR) and trade openness measured by total exports plus total imports as a percentage of GDP (OPEN). The definition of the variables are provided in Table 8 (see Appendix). 


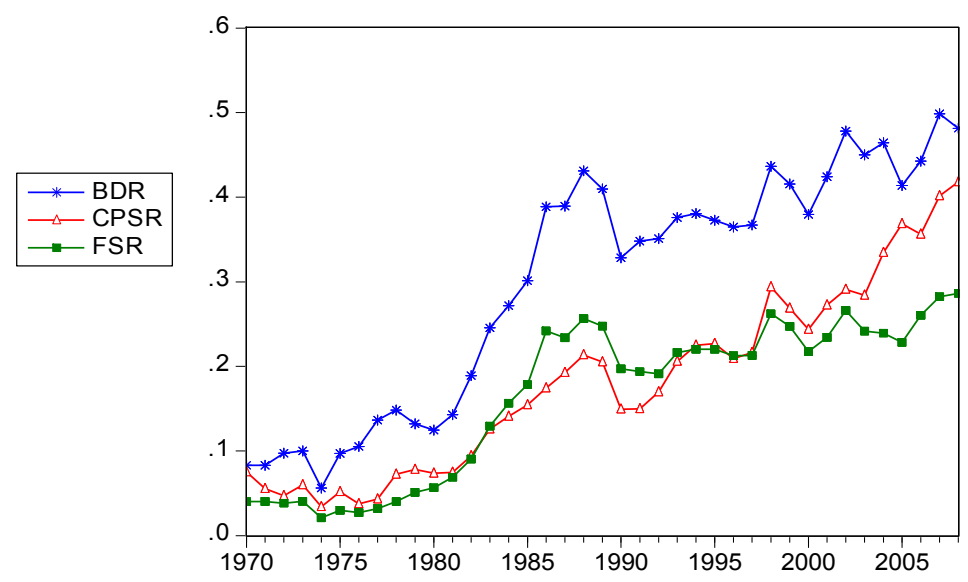

Figure 1. Trends of financial developments indicators in Saudi Arabia during the period 1970-2008

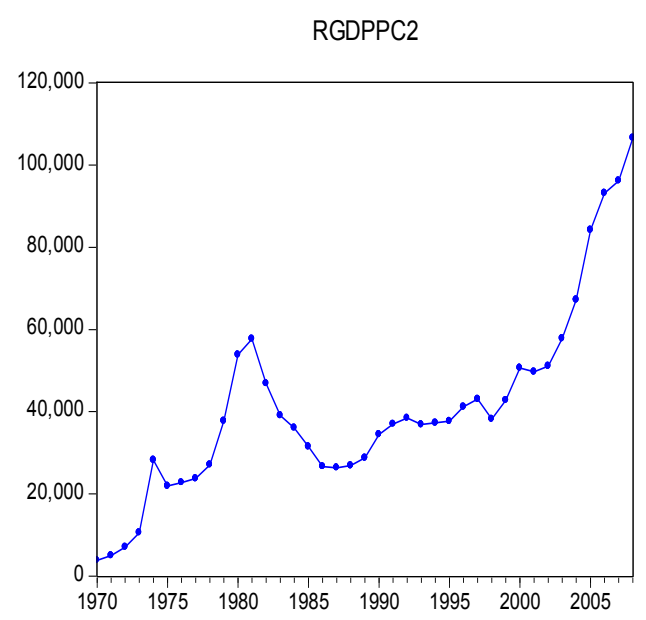

Figure 2. Economic growth in Saudi Arabia over time

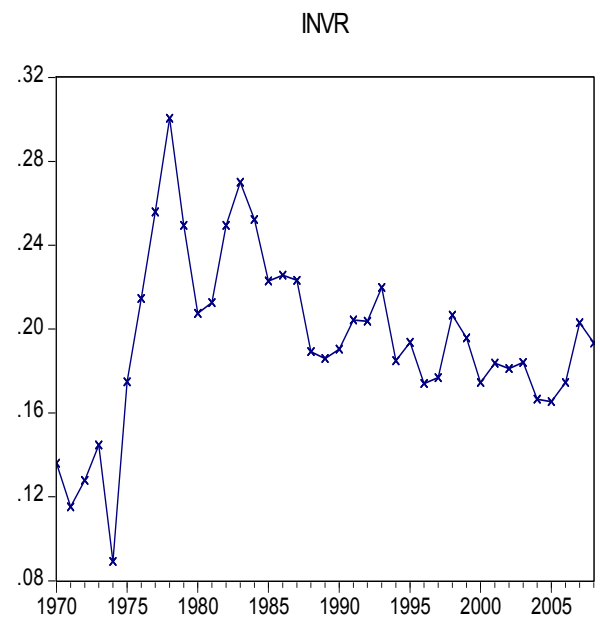

Figure 3. Investment ratio in Saudi Aradia during the period 1970-2008

\subsection{The Models}

In the empirical analysis, we apply a dynamic time series method for the linkage between financial development and economic growth. Following earlier studies in the literature, such as King and Levine (1993a), Demetriades and Hussein (1996), Boulila and Trabelsi (2004), Sbeiti (2006) and Handa and Khan (2008) among others, the 
models employed in this paper are based on the following augmented production functions:

$$
\begin{gathered}
Y_{t}=f\left(\text { Bdr }_{t}, \operatorname{Invr}_{t}, \text { Open }_{t}\right) \\
Y_{t}=f\left(\text { CP }_{t}, \operatorname{Invr}_{t}, \text { Open }_{t}\right) \\
Y_{t}=f\left(\text { Fsr }_{t}, \operatorname{Invr}_{t}, \text { Open }_{t}\right)
\end{gathered}
$$

Where Bdr is the ratio of bank deposits liabilities to GDP, Invr is the share of investment to GDP, Open is trade openness, $\mathrm{CP}$ is the ratio of credit private to GDP, and Fsr is the ratio of financial savings to GDP. Bank deposit liabilities (Bdr) is calculated by taking the difference between total bank deposits liabilities minus currency in circulation divided by nominal GDP. The dependent variable is proxied by real GDP per capita at constant prices (Y).

The above models can be specified in the following logarithmic forms:

$$
\begin{aligned}
& \text { Ln } Y=\alpha_{0}+\alpha_{1} \ln B d r+\alpha_{2} \ln \operatorname{In} v r+\alpha_{3} \ln \text { Open }+\varepsilon_{1} \\
& \text { Ln } Y=\beta_{0}+\beta_{1} \ln C P+\beta_{2} \ln \operatorname{In} v r+\beta_{3} \ln \text { Open }+\varepsilon_{2} \\
& \text { Ln } Y=\gamma_{0}+\gamma_{1} \ln F s r+\gamma_{2} \ln \operatorname{In} v r+\gamma_{3} \ln \text { Open }+\varepsilon_{3}
\end{aligned}
$$

where $\alpha \mathrm{s}, \beta \mathrm{s}$ and $\gamma s$ are the coefficients of financial development indicators, investment and trade openness. $\alpha_{0}, \beta_{0}$, $\gamma_{0}$ are constants and $\varepsilon_{\mathrm{t} 1}, \varepsilon_{t 2}, \varepsilon_{t 3}$, are error correction terms. The coefficients of Bdr, CP, Fsr, Invr and Open are expected to be positive. i.e., $\alpha_{1}>0, \alpha_{2}>0, \alpha_{3}>0, \beta_{1}>0, \beta_{2}>0, \beta_{3}>0, \gamma_{1}>0, \gamma_{2}>0$ and $\gamma_{3}>0$.

\subsection{Data Sources}

Annual data covering the period 1970-2008 are used in this study. The year 1970 was selected as the start of the sampling period due to data availability for all of the variables. The choice of annual data is also due availability. The sample period comprises 39 annual observations from 1970 to 2008 . All variables are expressed in national currency. Bank deposits to GDP, credit to the private sector to GDP, and financial savings to GDP are extracted from the Saudi Arabian Monetary Agency (SAMA), Annual Report, 2009, No.45. The investment ratio and the trade openness are extracted from the achievements of the development plans: Facts and Figures, Twenty-Fifth issue (1970-2008). Finally, the real GDP per capita is obtained from the World Development Indicators, World Bank Group.

Table 1. Summary statistics

\begin{tabular}{lcccccc}
\hline Variables & LY & LCP & LINVR & LOPEN & LBDR & LFSR \\
\hline Mean & 10.432 & -1.927 & -1.657 & -0.449 & -1.367 & -2.045 \\
Median & 10.537 & -1.7452 & -1.643 & -0.470 & -1.009 & -1.547 \\
Maximum & 11.577 & -0.873 & -1.202 & -0.090 & -0.696 & -0.881 \\
Minimum & 8.250 & -3.387 & -2.417 & -0.797 & -2.875 & -3.857 \\
Std. Dev. & 0.714 & 0.727 & 0.232 & 0.200 & 0.642 & 0.866 \\
Skewness & -1.305 & -0.468 & -0.972 & 0.057 & -0.816 & -0.767 \\
Kurtosis & 5.139 & 2.007 & 4.889 & 1.723 & 2.181 & 1.989 \\
Jarque-Bera & 18.505 & 3.028 & 11.939 & 2.672 & 5.413 & 5.488 \\
Probability & 0.000 & 0.220 & 0.003 & 0.263 & 0.067 & 0.064 \\
Sum & 406.857 & -75.167 & -64.617 & -17.509 & -53.328 & -79.753 \\
Sum Sq. Dev. & 19.373 & 20.103 & 2.053 & 1.513 & 15.640 & 28.521 \\
Observations & 39 & 39 & 39 & 39 & 39 & 39 \\
\hline
\end{tabular}

Table 2. Correlation matrix

\begin{tabular}{lcccccc}
\hline & LY & LBDR & LCP & LFSR & LINVR & LOPEN \\
\hline LY & 1 & 0.668 & 0.658 & 0.610 & 0.389 & 0.106 \\
LBDR & & 1 & 0.952 & 0.980 & 0.333 & -0.527 \\
LCP & & & 1 & 0.959 & 0.164 & -0.416 \\
LFSR & & & & 1 & 0.237 & -0.567 \\
LINVR & & & & & 1 & -0.122 \\
LOPEN & & & & & & 1 \\
\hline
\end{tabular}

Note. $\mathrm{Y}=\mathrm{RGDPPC}$ 
Table 1 presents summary statistics on the real GDPPC (economic growth), three financial development variables and two control variables used in the analyses. Table 1 shows descriptive statistics of all variables utilized in this study. The mean of the gross domestic product per capita is greater than the mean of all financial development and control variables. As we can see Table 1 illustrates that all variables satisfy the normality test. The Jarque-Bera normality test rejects the hypothesis that the residuals are normally distributed for these variables; LY, LINVR, LBDR and LFSR. In other words, the Jarque-Bera test rejects normality at the 5\% level for all above distributions respectively. This indicates that less than $5 \%$ of most of the variables satisfy the normality test. The skewness and kurtosis values in Table 1 show that all variables series are negatively skewed. On the contrary, LOPEN is positively skewed. The negative values for skewness show that the series' distributions are skewed to the left, and the positive values for skewness indicate that the series' distributions are skewed to the right. The values for kurtosis are not high (less than 3) for all variables (i.e., the distribution is flat (platykurtic) relative to the normal except for LY and LINVR (i.e., the distribution is peaked (leptokurtic) relative to the normal.

The strength of the relationship of variables is also estimated and reported in Table 2. The simple correlation of real GDPPC and the financial development indicators are presented in Table 2 which shows very high positive correlation between LBDR, LFSR and LY and between LFSR and LCP. The correlation between investment (LINVR) and other variables is positive but low, while the correlation between trade openness (LOPEN) and other variables is negative except with LY. In other words, economic activities are positively correlated with financial development variables (40 percent of the correlations are significantly positive). Moreover investment as \% of GDP is also associated positively with all variables. The trade openness as \% of GDP is negatively related with all variables except LY. The result states that all variables are moderately correlated except LOPEN which is weakly and negatively correlated with all variables. The results confirm that just about $40 \%$ of the correlations are significantly positive between economic activities and financial development variables on one hand and between financial development variables and control variables on the other hand. To obtain robust and significant results we therefore carry of tests for the time series properties of the series. The positive and negative trends in the data can be noticed from Figures 1,2 and 3 respectively.

\section{Unit Root Tests}

Unit root tests for the order of the integration of each variable are performed on both the original series and the first differences of the series, using both the ADF and DF-GLS methods. These tests are therefore applied to the level of variables as well as to their first differences. The null hypothesis tested is that the concerned series contains a unit root against the alternative hypothesis that the variable is stationary. The results of these tests are reported in Table 3 and Table 4. The results show that all variables are integrated of order one, I(1) at 5\% except (LInvr) which is an $\mathrm{I}(0)$. These results are consistent with previous literature that has found the majority of macroeconomic factors and financial development indicators to be non-stationary. Moreover, all variables are stationary in their first difference.

Table 3. Augmented dickey-fuller unit root test

\begin{tabular}{|c|c|c|c|c|c|c|}
\hline \multicolumn{7}{|c|}{ Null Hypothesis: Variable is not- Stationary ADF } \\
\hline Variables & & $\begin{array}{c}\text { Level } \\
\text { with constant }(\mathrm{C})\end{array}$ & $\begin{array}{c}\text { Level } \\
\text { With } \mathrm{C} \text { and trend }(\mathrm{T})\end{array}$ & $\begin{array}{l}\text { First differences } \\
\text { ( C ) }\end{array}$ & $\begin{array}{l}\text { First differences } \\
\text { ( C \&T })\end{array}$ & $\begin{array}{c}\text { Variable } \\
\text { type }\end{array}$ \\
\hline LY & & $-2.563(2)$ & $-2.979(2)$ & $-3.128 * *(0)$ & $-3.885 * *(3)$ & $\mathrm{I}(1)$ \\
\hline LBDR & & $-1.489(0)$ & $-1.725(0)$ & $-6.969 *(0)$ & $-7.050 *(0)$ & I(1) \\
\hline LCP & & $-0.484(1)$ & $-3.263 * * *(0)$ & $-7.777 *(0)$ & $-7.656 *(0)$ & $\mathrm{I}(0) / \mathrm{I}(1)$ \\
\hline LFSR & & $-1.069(1)$ & $-1.653(3)$ & $-8.646^{*}(0)$ & $-8.607 *(0)$ & $\mathrm{I}(1)$ \\
\hline LINVR & & $-2.684 * * *(0)$ & $-2.600(0)$ & $-7.216^{*}(0)$ & $-5.252 *(3)$ & $\mathrm{I}(0) / \mathrm{I}(1)$ \\
\hline LOPEN & & $-1.397(1)$ & $-0.515(0)$ & $-4.608 *(0)$ & $-4.758 *(0)$ & $\mathrm{I}(1)$ \\
\hline \multicolumn{7}{|c|}{ Critical Values } \\
\hline \multirow{3}{*}{$\begin{array}{l}\text { Significance } \\
\text { level }\end{array}$} & $1 \%$ & -3.616 & -4.253 & -3.627 & -4.253 & \\
\hline & $5 \%$ & -2.941 & -3.548 & -2.946 & -3.548 & \\
\hline & $10 \%$ & -2.609 & -3.207 & -2.612 & -3.207 & \\
\hline
\end{tabular}

Note. *,**, and *** represent significance at the $1 \%, 5 \%$ and $10 \%$ levels, respectively. The software E-views 6 was used for these tests. Figures within parentheses indicate lag length. 
Table 4. Dickey-fuller: generalized least square unit root test

\begin{tabular}{|c|c|c|c|c|c|c|}
\hline \multicolumn{7}{|c|}{ Null Hypothesis: Variable is not-stationary DF: GLS } \\
\hline \multicolumn{2}{|c|}{ Variables } & $\begin{array}{l}\text { Level } \\
\text { (C) }\end{array}$ & $\begin{array}{c}\text { Level } \\
\text { ( C\&T ) }\end{array}$ & $\begin{array}{c}\text { First differences } \\
\text { ( C ) }\end{array}$ & $\begin{array}{c}\text { First differences } \\
\text { ( C \& T ) }\end{array}$ & $\begin{array}{c}\text { Variable } \\
\text { type }\end{array}$ \\
\hline \multicolumn{2}{|c|}{ LY } & $-2.441 * * *(2)$ & $-2.786(2)$ & $-2.368(0)^{* *}$ & $-2.840(0)$ & $\mathrm{I}(0) / \mathrm{I}(1)$ \\
\hline \multicolumn{2}{|c|}{ LBDR } & $-0.454(0)$ & $-1.803(0)$ & $-6.903 *(0)$ & $-7.163 *(0)$ & $\mathrm{I}(1)$ \\
\hline \multicolumn{2}{|c|}{ LCP } & $-0.197(0)$ & $-2.780(0)$ & $-1.644 * * *(2)$ & $-6.931 *(0)$ & $\mathrm{I}(1)$ \\
\hline \multicolumn{2}{|c|}{ LFSR } & $-0.754(3)$ & $-1.817(3)$ & $-2.412 * *(2)$ & $-8.786 *(0)$ & $\mathrm{I}(1)$ \\
\hline \multicolumn{2}{|c|}{ LINVR } & $-2.162 * *(0)$ & $-2.454(0)$ & $-6.134 *(0)$ & $-6.966 *(0)$ & $\mathrm{I}(0) / \mathrm{I}(1)$ \\
\hline \multicolumn{2}{|c|}{ LOPEN } & $-1.461(1)$ & $-1.448(1)$ & $-4.133 *(0)$ & $-4.616 *(0)$ & $\mathrm{I}(1)$ \\
\hline \multicolumn{7}{|c|}{ Critical Values } \\
\hline \multirow{3}{*}{$\begin{array}{l}\text { Significance } \\
\text { level }\end{array}$} & $1 \%$ & -2.627 & -3.770 & -2.627 & -3.770 & \\
\hline & $5 \%$ & -1.950 & -3.190 & -1.950 & -3.190 & \\
\hline & $10 \%$ & -1.611 & -2.890 & -1.611 & -2.890 & \\
\hline
\end{tabular}

Note. ${ }^{*}, * *$, and $* * *$ represent significance at the $1 \%, 5 \%$ and $10 \%$ levels, respectively. The software E-views 6 was used for these tests. Figures within parentheses indicate lag length.

\section{Testing for Co-Integration Using the ARDL Approach}

This study uses the autoregressive distributed lag (ARDL) approach, suggested by Pesaran and Shin (1995, 1999) and extended by Pesaran et al. (2001), to test the existence of a long-run relationship (co-integration). The advantage of the bounds testing process, is that it is applicable irrespective of whether the underlying regressors are purely I(0), purely I(1) or mutually co-integrated. However, Ouattara (2004) and Ang (2009) declare that in the presence of I(2) variables the computed F-statistics provided by Pesaran et al. (2001) are not valid. As a result, unit root tests in the ARDL model may still be necessary to be sure that none of the variables is integrated of order 2 or above. This process, which depends on the estimation of an unrestricted error correction model (UECM), is preferred to the common Engle and Granger two step (1987) method and Johansen (1988) and Johnson and Juseliues (1990), which may not be appropriate when the sample size is too small. The UECM test is quite likely to have better statistical properties since it does not push the short-term dynamics into the residual term, as in the case of the Engle and Granger two-step (EG) method, see Pattichis (1999), Narayan and Smyth (2005) and Odhiambo (2010).

To apply the bounds test procedure for the specifications (1), (2) and (3) above, the error correction versions of the ARDL model are given respectively by the unrestricted error correction representation (UECM) of the ARDL as follows:

$$
\begin{aligned}
& \Delta \ln Y_{t}=\alpha_{0}+\sum_{i=1}^{n} \alpha_{1} \Delta \ln Y_{t-I}+\sum_{i=1}^{n} \alpha_{2} \Delta \ln B d r_{t-i}+\sum_{i=1}^{n} \alpha_{3} \Delta \ln \operatorname{In} v r_{t-I}+\sum_{i=1}^{n} \alpha_{4} \Delta \ln O_{\text {Open }}+\delta_{1} \ln \\
& Y_{t-1}+\delta_{2} \ln B d r_{t-1}+\delta_{3} \ln \operatorname{Inv}_{t-1}+\delta_{4} \ln \text { Open }_{t-1}+\varepsilon_{t 1} \\
& \Delta \ln Y_{t}=\beta_{0}+\sum_{i=1}^{n} \beta_{1} \Delta \ln Y_{t-I}+\sum_{i=1}^{n} \beta_{2} \Delta \ln B d r_{t-i}+\sum_{i=1}^{n} \beta_{3} \Delta \ln \operatorname{Invr}_{t-i}+\sum_{i=1}^{n} \beta_{4} \Delta \ln \text { Open }_{t-i} \text { Open }_{t-i}+\lambda_{1} \ln \\
& Y_{t-1}+\lambda_{2} \ln C p_{t-1}+\lambda_{3} \ln \operatorname{Invr}_{t-1}+\lambda_{4} \ln \text { Open }_{t-1}+\varepsilon_{t 2} \\
& \Delta \ln Y_{t}=\boldsymbol{\gamma}_{0}+\sum_{i=1}^{n} \gamma_{1} \Delta \ln Y_{t-i}+\sum_{i=1}^{n} \gamma_{2} \Delta \ln F s r_{t-i}+\sum_{i=1}^{n} \gamma_{3} \Delta \ln \operatorname{Inv} r_{t-i}+\sum_{i=1}^{n} \gamma_{4} \Delta \ln \text { Open }_{t-i}+\xi_{1} \ln Y_{t-1}+\xi_{2}
\end{aligned}
$$

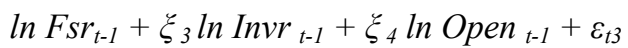

Where $\Delta$ denotes first difference, $\alpha_{0}, \beta_{0}$ and $\gamma_{0}$ are constants and $\varepsilon_{\mathrm{t} 1}, \varepsilon_{\mathrm{t} 2}$ and $\varepsilon_{\mathrm{t} 3}$ are white noise errors. Since we have annual observations, we select $n=2$ for the maximum order of lags in the ARDL model in all cases. The coefficients of the first difference variables are the short-term parameters, while the long-term elasticities are derived according to Bardsen (1989). The long-run elasticities obtained from estimating equation (4) are the coefficients of the once lagged explanatory variable (multiplied by a negative sign) divided by the coefficient of one lagged dependent variable, i.e., $-\left(\delta_{2} / \delta_{1}\right),-\left(\delta_{3} / \delta_{1}\right)$, and $-\left(\delta_{4} / \delta_{1}\right)$ respectively. For model 1 , the null hypothesis $\mathrm{H}_{0}: \delta_{1}=0, \delta_{2}=0, \delta_{3}=0$ and $\delta_{4}=0$ and is tested against the alternative $\mathrm{H}_{1}: \delta_{1} \neq 0$ or $\delta_{2} \neq 0$ or $\delta_{3} \neq 0$ or $\delta_{4} \neq 0$. The recommended statistic is the F-statistic for the joint significance of $\delta_{1}, \delta_{2}, \delta_{3}$, and $\delta_{4}$. To compute the F-statistic it is required to run the following regression: 


$$
\Delta \ln Y_{t}=\alpha_{0}+\alpha_{1} \Delta \ln Y_{t-i}+\alpha_{2} \Delta \ln B d r_{t-i}+\alpha_{3} \Delta \ln \operatorname{In} v r_{t-i}+\alpha_{4} \Delta \ln \text { Open }_{t-i}+\varepsilon_{t}
$$

and a variable addition test is subsequently made by including the following:

$$
\delta_{1} \ln Y_{t-1}, \delta_{2} \ln B d r_{t-1}, \delta_{3} \ln \operatorname{Invr}_{t-1,} \delta_{4} \ln \text { Open }_{t-1}
$$

We repeated the above process for models 2 and 3. Pesaran et al. (2001) have established that, under the null hypothesis of no co-integration and regardless of the degree of integration, the obtained F-statistic is non-standard. They develop two bounds of critical values for the different model specifications: the upper bound applies when all variables are integrated of order one, I(1) and the lower bound applies when all the variables are stationary, I(0). If the calculated F-statistic, for a selected level of significance, exceeds the upper critical bound, then the null hypothesis of no co-integration is rejected. If the F- statistic is lower than, the lower bound, then the null hypothesis cannot be rejected. If, however, the calculated F-statistic lies between the lower and the upper bounds, conclusive inference may not be made. As Pesaran et al. (2001) note, a shortcoming of their method is that it is not appropriate in situations where there are more than one co-integrating vectors. After confirmation of the existence of a long-run relationship among the variables, the long-run and short-run models can be derived using information criteria such as the Schwartz Bayesian criterion, Akaike information criterion and Hannan-Quinn criterion.

\section{Empirical Results}

\subsection{ARDL Model Results}

The next step of the procedure is to estimate the coefficients of the long-run relationships and associated error correction model (ECM) using the ARDL model. The order of distributed lag on the dependent variables were selected by the Akaike information Criterion (AIC) and turned out to be two. The Akaike information Criterion selects an ARDL $(2,1,1,0)$ for model one and ARDL $(2,2,2,1)$ for models two and three respectively.

Table 4 shows the results of the ARDL approach for the existence of co-integration. The F-statistic 8.1350 is above the 1 percent critical value bounds [4.29, 5.61], i.e., the null hypothesis of no co-integration can be rejected. Therefore, there is one long-run relationship among the variables under investigation. Substituting LBdr by LCp as the alternative measure for financial development, and replicating the same process as above, yields an F-statistic of 11.7681 which indicates the existence of co-integration in this alternative specification as well. Substituting LCp by LFsr as the alternative measure for financial development, and replicating the same process as above yields an F-statistic of 9.9430 which suggests the existence of co-integration in this alternative specification as well (Note 4).

Table 4. ARDL Bounds test for the existence of co-integration

\begin{tabular}{llllllc}
\hline$F$ - Statistic & \multicolumn{2}{l}{$1 \%$ Critical value } & \multicolumn{2}{l}{$5 \%$ Critical value } & \multicolumn{2}{l}{$10 \%$ Critical value } \\
\hline$F_{Y}(Y / B D R, I N V R$, OPEN $)=8.1350^{*}$ & $I(0)$ & $I(1)$ & $I(0)$ & $I(1)$ & $I(0)$ & $I(1)$ \\
$F_{\mathrm{Y}}(\mathrm{Y} / \mathrm{CP}, \mathrm{INVR}, \mathrm{OPEN})=11.7681^{*}$ & 4.29 & 5.61 & 3.23 & 4.35 & 2.72 & 3.77 \\
$\mathrm{~F}_{\mathrm{Y}}(\mathrm{Y} / \mathrm{FSR}, \mathrm{INVR}, \mathrm{OPEN})=9.9430^{*}$ & & &
\end{tabular}

Note. computed F-statistic (Wald test) $=\mathbf{8 . 1 3 5 0 ,} 11.7681$ and 9.9430 (three regressors with lags, k=3). The upper and lower bounds were obtained using unrestricted intercept and no trend. * denote rejecting the null at 1 percent level. The critical values are obtained from Pesaran et al. (2001), Table CI (III), p. 300.

Table 5 displays the long-run estimated coefficients based on the Akaike information criterion (AIC). The selected ARDL $(2,1,1,0)$, $(2,2,2,1)$ passes the standard diagnostic tests (serial correlation, functional form, normality and heteroscedasticty) (Note 5). It is observed that financial development has contributed positively to output growth in the long-run. Table 5 indicates that bank deposits and credit to private sector have a motivating impact on economic growth, whilst, financial savings has not. The estimated coefficients 0.383 and 0.443 are significant, at $5 \%$ level. In fact a $1 \%$ increase in the bank deposits to GDP ratio is associated with a $0.38 \%$ increase in output level. The link is also confirmed by utilizing credit to private sector and it was estimated to be slightly higher at $0.44 \%$. The investment ratio does not have a significant impact on economic growth. The estimated coefficients are negative and statistically insignificant for all models. This result is inconsistent with economic theory and the literature such as Almasaied (2004), Tang, Selvanathan and Selvanathan (2008) and Adams (2009) who suggests a positive and significant relationship between domestic investment and economic growth in Asia, China and Sub-Saharan Africa, respectively. Finally, trade openness appears to have a significant impact on real GDP per capita for all models. The estimated coefficients are positive and statistically significant 
at $1 \%$ level, particularly for models one and two. For model three, the estimated coefficient is positive and statistically significant at 5\% level.

Table 5. Estimated long-run coefficients based on ARDL model

\begin{tabular}{|c|c|c|c|c|c|c|c|c|c|}
\hline Regressor & $\begin{array}{l}\text { Coefficients AIC } \\
(2,1,1,0) \text { Model } 1\end{array}$ & t-ratio & $\begin{array}{c}P \text { - } \\
\text { value }\end{array}$ & $\begin{array}{l}\text { Coefficients AIC } \\
(2,2,2,1) \text { Model } 2\end{array}$ & t-ratio & $\begin{array}{c}P- \\
\text { value }\end{array}$ & $\begin{array}{l}\text { Coefficients AIC } \\
(2,2,2,1) \text { Model } 3\end{array}$ & t-ratio & $\begin{array}{c}P \text { - } \\
\text { value }\end{array}$ \\
\hline$L B D R$ & $0.383 * *$ & 2.155 & .040 & & & & & & \\
\hline$L C P$ & & & & $0.443 * *$ & 2.616 & 0.015 & & & \\
\hline$L F S R$ & & & & & & & 0.334 & 1.4838 & 0.150 \\
\hline$L I N V R$ & -0.645 & -1.267 & 0.215 & -0.152 & -0.202 & 0.842 & -0.188 & -2.209 & 0.836 \\
\hline LOPEN & $2.591 *$ & 5.751 & 0.000 & $1.575^{*}$ & 3.407 & 0.002 & $1.906^{* *}$ & 2.554 & 0.017 \\
\hline Constant & $11.689^{*}$ & 14.946 & 0.000 & $11.985^{*}$ & 8.790 & 0.000 & $11.998 *$ & 7.115 & 0.000 \\
\hline
\end{tabular}

Note. Dependent variable is LY. * Significant at $1 \%, * *$ significant at $5 \%$. *** significant at $10 \%$.

Results from Table 4 confirm that the variables under consideration are co-integrated; this provides support for the use of an error correction model (ECM) to examine the short run relationship. Table 6 presents the estimated results based on Akaike information criterion (AIC). The adjusted $\mathrm{R}^{2} \mathrm{~s}$ are $0.953,0.917$ and 0.915 respectively, suggesting good fits. Moreover, the computed F-statistics clearly reject the null hypothesis that all regressions have zero coefficients. The error correction coefficients are $-0.147,-0.185$ and -0.135 have the expected negative sign and are highly significant (at 1\% level). This supports the findings of a long-run relationship between the variables in each model.

Also from Table 6, model one indicates that the effect of financial development on output has been negative and significant in the short-run. The coefficients for some of the independent variables are not well-behaved and do not have the expected sign, such as credit to the private sector, credit to the private sector lagged one period, financial savings and the investment ratio. However, the investment ratio lagged one period appear to have a positive and significant impact on economic growth at $5 \%$ level for model two and model three. For model one the investment ratio lagged one period seems to have a positive impact but is statistically insignificant. The trade openness ratio has a positive and statistically highly significant impact on economic growth (at $1 \%$ level) for all models.

Table 6. Error correction representation for the selected ARDL model

\begin{tabular}{|c|c|c|c|c|c|c|c|c|c|}
\hline Regressor & $\begin{array}{l}\text { Coefficients AIC } \\
(2,1,2,0) \text { Model } 1\end{array}$ & t-ratio & $\begin{array}{l}P \text { - } \\
\text { value }\end{array}$ & $\begin{array}{l}\text { Coefficients AIC } \\
(2,2,2,1) \text { Model } 2\end{array}$ & t-ratio & $\begin{array}{l}P \text { - } \\
\text { value }\end{array}$ & $\begin{array}{l}\text { Coefficients AIC } \\
(2,2,2,1) \text { Model } 3\end{array}$ & t-ratio & $\begin{array}{l}P \text { - } \\
\text { value }\end{array}$ \\
\hline$\triangle L B D R$ & $-0.529 *$ & -5.43 & 0 & & & & & & \\
\hline$\triangle L C P$ & & & & -0.0359 & -0.418 & 0.679 & & & \\
\hline$\triangle L C P 1$ & & & & 0.136 & 1.618 & 0.117 & & & \\
\hline$\triangle L F S R$ & & & & & & & -0.209 & -1.604 & 0.12 \\
\hline$\triangle L F S R 1$ & & & & & & & 0.17 & 1.337 & 0.192 \\
\hline$\Delta L I N V R$ & $-0.414^{*}$ & -4.414 & 0 & $-0.605^{*}$ & -4.281 & 0 & $-0.5873 *$ & -4.267 & 0 \\
\hline$\triangle L N V R 1$ & 0.135 & 1.663 & 0.107 & $0.259 * *$ & 2.356 & 0.025 & $0.276^{* *}$ & 2.222 & 0.034 \\
\hline$\triangle L O P E N$ & $0.381 *$ & 5.612 & 0 & $0.722 *$ & 4.769 & 0 & $0.603^{*}$ & 3.939 & 0 \\
\hline$\Delta C$ & $1.719^{*}$ & 4.226 & 0 & $2.215 * *$ & 2.749 & 0.01 & $1.626^{* * *}$ & 2.485 & 0.019 \\
\hline $\operatorname{ECM}(-1)$ & $-0.147^{*}$ & -5.289 & 0 & $-0.185^{*}$ & -3.734 & 0.001 & $-0.135^{*}$ & -3.331 & 0.002 \\
\hline$R$-square & 0.964 & & & 0.94 & & & 0.937 & & \\
\hline$D W$ & 1.524 & & & 2.27 & & & 1.86 & & \\
\hline
\end{tabular}

To ensure the robustness of our results we employ structural stability tests on the parameters of the long-run results based on the cumulative sum (CUSUM) and the cumulative sum of square (CUSUMSQ) tests proposed by Brown et al. (1975). A graphical representation of CUSUM and CUSUMSQ statistics are provided in figures 1,2 and 3. If the plot of the CUSUM and CUSUMSQ remains within the 5 per cent critical bound and the null hypothesis that all coefficients are stable cannot be rejected. The plots indicate that none of the straight lines (drawn at the 5 percent level) are crossed by CUSUM and CUSUMSQ. I.e. the plots of both the CUSUM and CUSUMSQ are within the boundaries and therefore these statistics confirm the stability of the long-run 
coefficients of the RGDP per capita function in model 4,5 and 6, respectively.

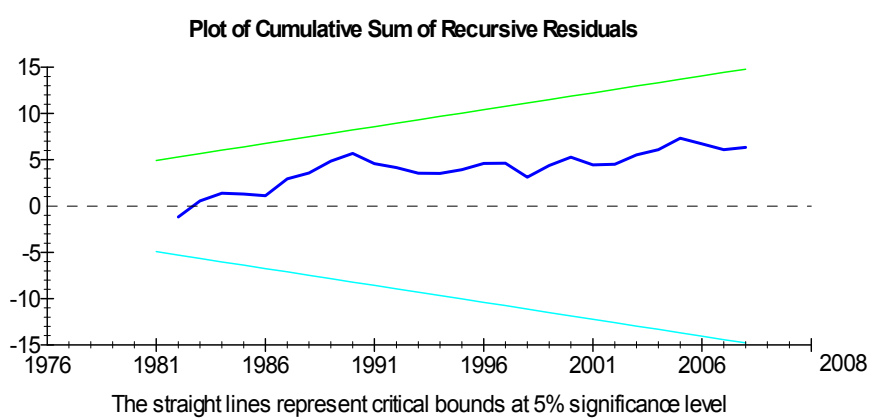

Plot of Cumulative Sum of Squares of Recursive Residuals

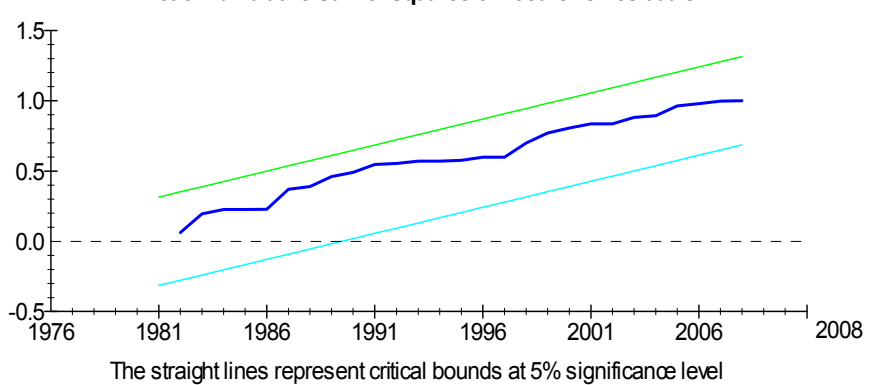

Figure 4. Plots of CUSUM and CUSUMSQ statistics for stability test (model 1)

Plot of Cumulative Sum of Recursive Residuals

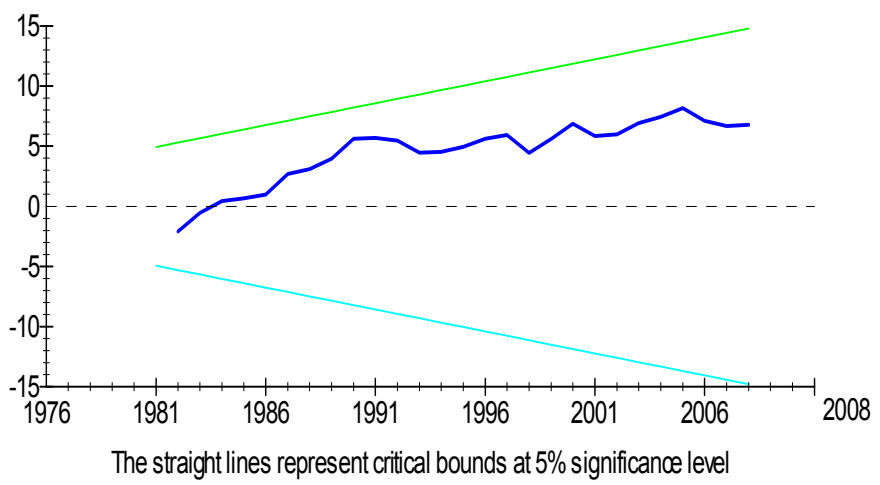

Plot of Cumulative Sum of Squares of Recursive Residuals

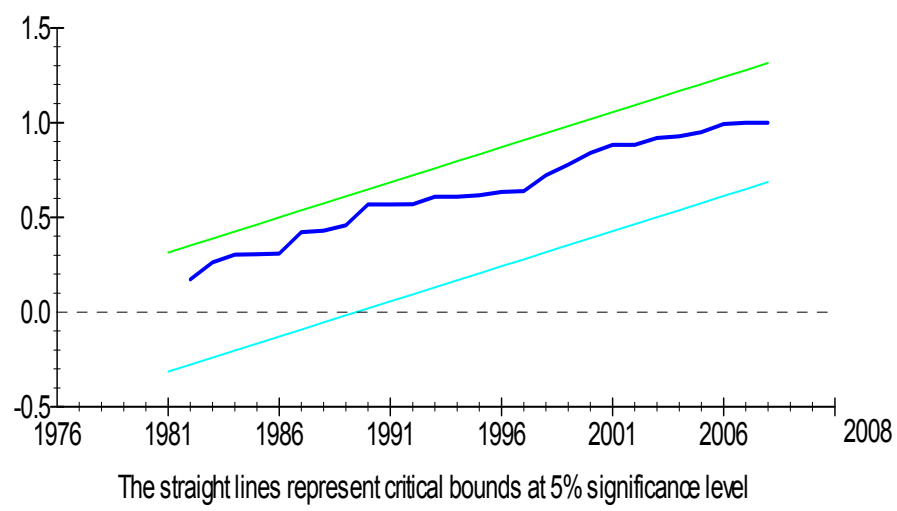

Figure 5. Plots of CUSUM and CUSUMSQ statistics for stability test (model 2) 


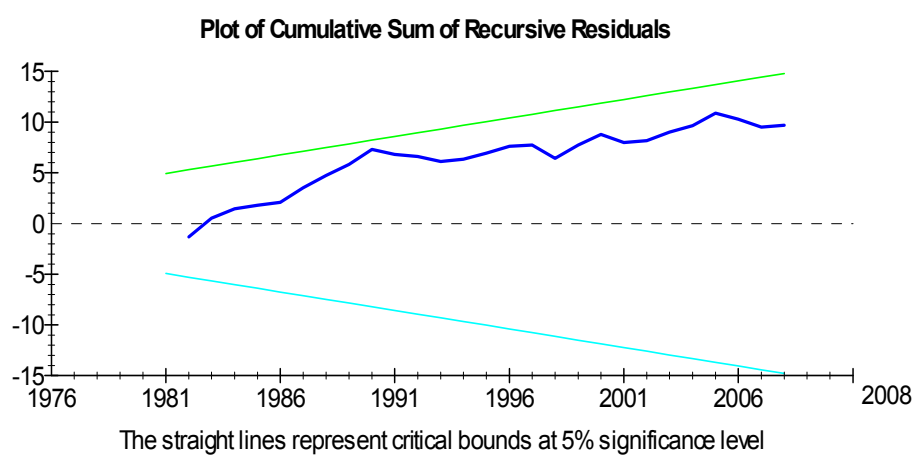

Plot of Cumulative Sum of Squares of Recursive Residuals

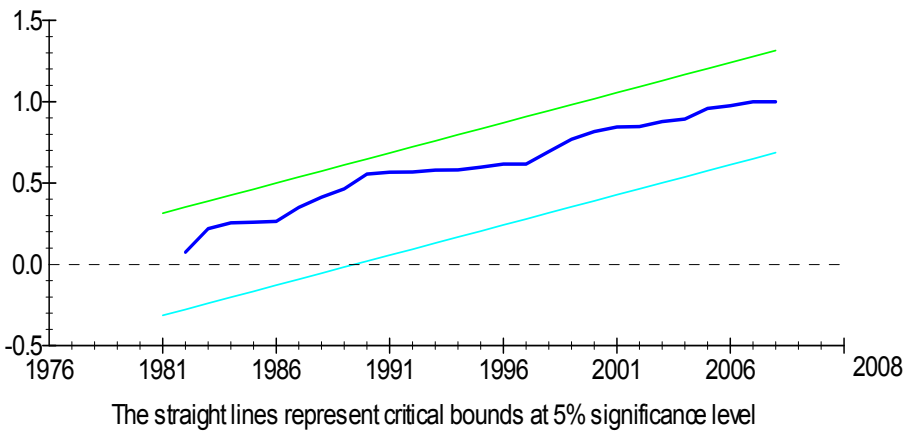

Figure 6. Plots of CUSUM and CUSUMSQ statistics for stability test (model 3)

\subsection{Granger Causality Tests Results}

The Granger Causality test results reported in Table 7 suggest that there is bidirectional causality between bank deposits ratio, financial savings ratio and economic growth for models one and three, respectively. Causality test results also suggest that the relationship between credit to private sector and economic growth is unidirectional and running from economic growth to credit to the private sector.

Table 7. Granger causality tests results based on VECM-wald test

\begin{tabular}{|c|c|c|c|c|c|}
\hline $\begin{array}{c}\text { Dependent } \\
\text { Variable }\end{array}$ & $\Delta \mathbf{L Y}$ & $\triangle$ LBDR & SLINVR & $\triangle$ LOPEN & $\begin{array}{c}\text { ECT (-1) } \\
\text { [t -stat] }\end{array}$ \\
\hline \multicolumn{6}{|c|}{ Chi-sq (Wald Statistics) (Prob) } \\
\hline \multicolumn{6}{|l|}{ Model 1} \\
\hline$\Delta \mathbf{L Y}$ & & $44.900 *(0.000)$ & $17.747 *(0.000)$ & $11.208 *(0.004)$ & $-0.301[-6.074]$ \\
\hline$\Delta$ LBDR & $22.348 *(0.000)$ & & $13.957 *(0.001)$ & $3.296(0.192)$ & $0.313[7.259]$ \\
\hline$\Delta$ LINV & $4.196(0.123)$ & $1.777(0.411)$ & & $2.007(0.367)$ & $0.264[5.362]$ \\
\hline$\triangle$ LOPEN & $1.915(0.384)$ & $3.274(0.195)$ & $1.174(0.556)$ & & $-0.106[-3.219]$ \\
\hline Model 2 & & $\Delta \mathrm{LCP}$ & & & \\
\hline$\Delta \mathbf{L Y}$ & & $13.428 *(0.001)$ & $0.702(0.704)$ & $1.756(0.416)$ & $-0.595[-5.968]$ \\
\hline$\Delta \mathrm{LCP}$ & $2.771(0.250)$ & & $10.750 *(0.005)$ & $1.918(0.383)$ & $0.567[3.996]$ \\
\hline$\Delta$ LINV & $12.816 *(0.002)$ & $0.194 *(0.098)$ & & $0.819(0.664)$ & $0.369[3.598]$ \\
\hline$\triangle$ LOPEN & $2.660(0.265)$ & $0.917(0.632)$ & $2.632(0.268)$ & & $-0.185[-2.234]$ \\
\hline Model 3 & & $\Delta$ LFSR & & & \\
\hline$\Delta \mathbf{L Y}$ & & $20.588 *(0.000)$ & $14.210 *(0.001)$ & $7.159 * *(0.028)$ & $-0.244[-4.722]$ \\
\hline$\Delta$ LFSR & $52.555 *(0.000)$ & & $36.332 *(0.000)$ & $6.253 * *(0.044)$ & $0.275[5.377]$ \\
\hline$\Delta$ LINV & $33.159 *(0.000)$ & $22.224 *(0.000)$ & & $8.040 * *(0.018)$ & $0.123[2.358]$ \\
\hline$\triangle$ LOPEN & $6.977 * *(0.031)$ & $6.667 * *(0.036)$ & $3.667(0.160)$ & & $-0.061[-1.562]$ \\
\hline
\end{tabular}

Note. ***and $* * *$ significant at $1 \%$ and $5 \%$ significant level respectively.

\section{Conclusion}

This paper has examined the empirical relationship between financial development and economic growth for the 
case of Saudi Arabia over the period 1970 to 2008, applying the co-integration testing technique via estimations of an ARDL model. The analysis was performed employing three different indicators for financial development. Namely: the ratio of bank deposits liabilities to GDP, the ratio of private credit to GDP and the ratio of financial savings to GDP. The results indicate that, in the long-run, for all models, financial development indicators and trade openness positively influence economic growth, except for the financial development indicator for model three, while the share of investment is negatively associated with output, but insignificant. In addition, in the short- run, for all models, financial development indicators appear to have negative and insignificant impacts on economic growth, except for model one, which seems statistically significant. However, economic growth is negatively and significantly affected by changes in the share of investment. The share of investment lagged one period affects economic growth positively and significantly at 5\% level, except in model one which seems insignificant. Causality results support both the supply-leading and the demand-following hypothesis for Saudi Arabia. This finding is at odds with existing empirical evidence in the literature which suggests that developing countries have a supply-leading causality pattern of development rather than a demand-following one.

\section{Acknowledgments}

The authors are grateful to Prof. Alan Speight, Dr. Dimitrios Vougas, and Dr. B. Ouattara, Swansea University, UK for their valuable comments and suggestions.

\section{References}

Abu-Bader, S., \& Abu-Qarn, A. S. (2008). Financial Development and Economic Growth: the Egyptian Experience. Journal of Policy Modelling, 30(5), 887-898. http://dx.doi.org/10.1016/j.jpolmod.2007.02.001

Adams, S. (2009). Foreign Direct Investment, Domestic Investment, and Economic Growth in Sub-Saharan Africa. Journal of Policy Modelling, 31, 939-949. http://dx.doi.org/10.1016/j.jpolmod.2009.03.003

Ang, J. S. (2009). Financial Development and Economic Growth in Malaysia. Abingdon. New York, NY: Routledge.

Ang, J. B., \& McKibbin, W. J. (2007). Financial Liberalization, Financial Sector Development and Growth: Evidence from Malaysia. Journal of Development Economics, 84(1), 215-233. http://dx.doi.org/10.1016/j.jdeveco.2006.11.006

Albatel, A. H. (2003). Money, Finance and Economic Growth the Case of Saudi Arabia. Economic Research Fourm (ERF), Annual Conference, Egypt.

Almasaied, S. W. (2004). Foreign Direct Investment, Domestic Investment and Economic Growth: Evidence from Asean-5. Ph D thesis, University Putra Malaysia.

Arestis, P. (2005). Financial Liberalization and the Relationship between Finance and Growth. University of Cambridge, Centre for Economic and Public Policy, CEPP Working Paper No. 05/05.

Bagehot, W. (1873). Lombard Street: A Description of the Money Market. Homewood, Illinois, United States: Irwin.

Bardsen, G. (1989). Estimation of Long-Run Coefficients in Error Correction Models. Oxford Bulletin of Economics and Statistics, 51, 345-350. http://dx.doi.org/10.1111/j.1468-0084.1989.mp51003008.x

Boulila, G., \& Trabelsi, M. (2002). Financial Development and Long-Run Growth: Granger Causality in a Bivariate VAR Structure. Evidence from Tunisia: 1962-1997.

Boulila, G., \& Trabelsi, M. (2004). The Causality Issue in the Finance and Growth Nexus: Empirical Evidence from Middle East and North African Countries. Mimeo Central Bank of Lesotho. Quarterly Review, 23(3).

Brown, R. L., Durbin, J., \& Evans, J. M. (1975). Techniques for Testing the Constancy of Regression Relations over time. Journal of the Royal Statistical Society, (37), 149-163.

Chaudhuri, K., \& Smiles, S. (2004). Stock Market and Aggregate Economic Activity: Evidence from Australia. Applied Financial Economics, 14, 121-129. http://dx.doi.org/10.1080/0960310042000176399

De Gregorio, J., \& Guidotti, P. E. (1995). Financial Development and Economic Growth. World Development, 23, 433-448. http://dx.doi.org/10.1016/0305-750X(94)00132-I

Demetriades, P. O., \& Hussein, K. A. (1996). Does Financial Development Cause Economic Growth? Time-Series Evidence from 16 Countries. Journal of Development Economics, 51(2), 387-411. http://dx.doi.org/10.1016/S0304-3878(96)00421-X

Edwards, S. (1992). Trade Orientation, Distortions and Growth in Developing Countries. Journal of 
Development Economics, 39(1), 31-57. http://dx.doi.org/10.1016/0304-3878(92)90056-F

Engle, R. F., \& Granger, C. W. J. (1987). Co-Integration and Error Correction: Representation, Estimation, and Testing. Econometrica, 55(2), 251-276. http://dx.doi.org/10.2307/1913236

Fry, M. J. (1978). Money and Capital or Financial Deepening in Economic Development? Journal of Money, Credit, and Banking, 10(4), 464-475. http://dx.doi.org/10.2307/1991576

Garcia, V. F., \& Liu, L. (1999). Macroeconomic Determinants of Stock Market Development. Journal of Applied Economics, 2(1), 29-59.

Gupta, K. L. (1984). Finance and Economic Growth in Developing Countries. London: Croom Helm.

Gurley, J. G., \& Shaw, E. S. (1955). Financial Aspects of Economic Development. American Economic Review, 45(9), 515-538.

Gurley, J. G., \& Shaw, E. S. (1960). Money in a Theory of Finance (Washington: Brookings Institution).

Handa, J., \& Khan, S. R. (2008). Financial Development and Economic Growth: A symbiotic Relationship. Applied Financial Economics, 18, 1033-1049. http://dx.doi.org/10.1080/09603100701477275

Hussein, K. (1999). Finance and Growth in Egypt. Paper prepared for the Workshop on Financial Development Organized by EPIC and ECES. Cairo, Egypt.

Emmanuel, A. (1997). Financial Development and Growth: Theory and Time Series Evidence from 26 Countries Centre d'Etudes et de Recherches sur le Développement International (CERDI) Université d'Auvergne, Clermont-Ferrand, France.

Johansen, S. (1988). Statistical Analysis of Cointegration Vectors. Journal of Economic Dynamics and Control, 12(2-3), 231-254. http://dx.doi.org/10.1016/0165-1889(88)90041-3

Johansen, S., \& Juselius, K. (1990). Maximum likelihood Estimation and Inference on Co-integration with Applications to the Demand for Money. Oxford Bulletin of Economics and Statistics, 52(2), 169-210. http://dx.doi.org/10.1111/j.1468-0084.1990.mp52002003.x

Jung, W. S. (1986). Financial Development and Economic Growth: International Evidence. Economic Development and Cultural Change, 34(2), 333-346. http://dx.doi.org/10.1086/451531

Kar. M., Nazlioglu, S., \& Agir, H. (2010). Financial Development and Economic Growth Nexus in the MENA Countries: Bootstrap Panel Granger Causality Analysis. Economic Modeling.

Khan, M. A., Abdul, Q., \& Sheikh, S. A. (2005). Financial Development and Economic Growth: The Case of Pakistan. The Pakistan Development Review, 44(4 Part II), 819-837.

Khan, S. M., \& Senhadji, A. S. (2000). Financial Development and Economic Growth: An Overview. IMF Working Paper 00/209, Washington, D.C. http://dx.doi.org/10.5089/9781451874747.001

King, R. G., \& Levine, R. (1993a). Finance and Growth: Schumpeter Might be Right. The Quarterly Journal of Economics, 108(3), 717-737. http://dx.doi.org/10.2307/2118406

King, R. G., \& Rose, L. (1993b). Finance, Entrepreneurship, and Growth. Journal of Monetary Economics, 32, 513-542. http://dx.doi.org/10.1016/0304-3932(93)90028-E

Liang, Q., \& Teng, J. Z. (2006). Financial Development and Economic Growth: Evidence from China. China Economic Review, 17, 395-411. http://dx.doi.org/10.1016/j.chieco.2005.09.003

Levine, R. (1997). Financial Development and Economic Growth: Views and Agenda. Journal of Economic Literature, 35(2), 688-726.

Levine, R. (1998). The legal Environment, Banks, and Long-Run Economic Growth. Journal of Money, Credit and Banking, 30(3), 596-613. http://dx.doi.org/10.2307/2601259

Levine, R., \& Zervos, S. (1998). Stock Markets, Banks, and Economic Growth. The American. Economic Review, 88(3), 537-558.

Levine, R., Loayza, N., \& Beck, T. (2000). Financial Intermediation and Growth: Causality and Causes. Journal of Monetary Economics, 46, 31-77. http://dx.doi.org/10.1016/S0304-3932(00)00017-9

Lucas, R. E. Jr. (1988). On the Mechanics of Economic Development. Journal of Monetary Economics, 22(1), 3-42. http://dx.doi.org/10.1016/0304-3932(88)90168-7

McKinnon, R. I. (1973). Money and Capital in Economic Development. Washington, DC: Brookings Institution. 
Ministry of Economy and Planning. Achievements of the Development Plans; Facts and Figures, Twenty-Five Issue, 1970-2008.

Murinde, V., \& Eng, F. (1994). Financial Development and Economic Growth in Singapore: Demand-following of Supply-leading ? Applied Financial Economics, 4, 391-404. http://dx.doi.org/10.1080/758518671

Narayan, P. K., \& Smyth, R. (2005). Temporal Causality and the Dynamics of Democracy, Emigration and Real Income in Fiji. International Review of Applied Economics, 19(2), $245-261$. http://dx.doi.org/10.1080/02692170500031356

Naceur, S., Ghazouuani, S., \& Omaran, M. (2007). The Determinants of Stock Market Development in the Middle-Eastern and North African region. Managerial Finance, 33(7), 477-489. http://dx.doi.org/10.1108/03074350710753753

Nili, M., \& Rastad, M. (2007). Addressing the Growth Failure of the Oil Economies: the Role of Financial Development. The Quarterly Review of Economics and Finance, 46(5), 726-740. http://dx.doi.org/10.1016/j.qref.2006.08.007

Odhiambo, N. M. (2010). Finance-Investment-Growth Nexus in South Africa: An ARDL-Bounds Testing Procedure. Economic Change Restructuring. http://dx.doi.org/10.1007/s10644-010-9085-5

Onafowora, O., \& Owoye, O. (1998). Can Trade Liberalization Stimulate Economic Growth in Africa? World Development, 26(3), 497-506. http://dx.doi.org/10.1016/S0305-750X(97)10058-4

Ouattara, B. (2004). The Impact of Project Aid and Programme Aid on Domestic Savings: A Case Study of Cote d'Ivoire. Centre for the Study of African Economies Conference on Growth, Poverty Reduction and Human Development in Africa.

Outreville, J. F. (1999). Financial Development, Human Capital and Political Stability. UNCTAD Discussion Paper 142. United Nations Conference on Trade and Development. Geneva, Switzerland.

Pesaran, M. H., \& Shin, Y. (1995). Autoregressive Distributed Lag Modeling Approach to Co-integration Analysis. DAE Working Paper Series No 9514. Department of Economics, University of Cambridge.

Pesaran, M. H., \& Shin, Y. (1999). An Autoregressive Distributed Lag Modeling Approach to Co-integration Analysis, in Storm, S., end, Econometrics and Economic Theory in the 20th Century: the Ragnar Frish Centennial Symposium. Cambridge: Cambridge University Press.

Pesaran, M. H., Shin, Y., \& Smith, R. J. (2001). Bound Testing Approaches to the Analysis of Level Relationships. Journal of Applied Econometrics, 16, 289-326. http://dx.doi.org/10.1002/jae.616

Pittichis, C. A. (1999). Price and Income Elasticities of Disaggregated Import Demand: Results from UECMs and an Application. Applied Economics, 31, 1061-1071. http://dx.doi.org/10.1080/000368499323544

Rousseau, P. L., \& Wachtel, P. (2000). Inflation Thresholds and the Finance-Growth Nexus. Journal of International Money and Finance, 21, 777-793. http://dx.doi.org/10.1016/S0261-5606(02)00022-0

Saci, K., \& Holden, K. (2008). Evidence on Growth and Financial Development using Principal Components. Applied Financial Economics, 18, 1549-1560. http://dx.doi.org/10.1080/09603100701720286

Saudi Arabian Monetary Agency (SAMA). (2009). Annual report. No. 45, Riyadh, Saudi Arabia.

Sbeiti, W. (2006). On The Causal Relationship Between Financial Sector Development and Economic Growth: Some Empirical Evidence For the GCC Countries. Review Kuwait Economic, 20.

Schumpeter, J. A. (1911). The Theory of Economic Development. Cambridge: Harvard University Press.

Seetanah, B. (2008). Financial Development and Economic Growth: an ARDL Approach for the case of the Small Island State of Mauritius. Applied Economics Letters, 15, 809-813. http://dx.doi.org/10.1080/13504850600770889

Shaw, E. S. (1973). Financial Deepening in Economic Development. London: Oxford University Press.

Tang, S., Selvanathan, E. A., \& Selvanathan, S. (2008). Foreign Direct Investment, Domestic Investment and Economic Growth in China: A Time Series Analysis. The World Economy, 1292-1309. http://dx.doi.org/10.1111/j.1467-9701.2008.01129.x

Trabelsi, M. (2002). Finance and Growth: Empirical Evidence from Developing Countries, 1960-1990. Cahpter 13, Centre interuniversitaire de recherche en économie quantitative (CIREQ), Université de Montréal, and IHEC, Carthage, May 2002. 
Vazakidis, A., \& Adamopoulous, A. (2009). Financial Development and Economic Growth An Empirical Analysis for Greece. American Journal of Applied Sciences. Retireved from http://findarticles.com/p/articles/mi_7109/is_7_6/ai_n39142027/

World Bank. (1989). World Development Report. New York: Oxford University Press for the World Bank.

World Bank. World Development Indicators, Database. Retrieved from http://data.worldbank.org/data-catalog

\section{Notes}

Note 1 . Arestis $(2005 ;$ p. 2) goes back in history regarding the roots of the relationship between finance and economic growth. "Its roots can be traced in Lydia of Asia Minor when the first money was in evidence. The first signs of public debate, however, on the relationship between finance and growth, and indeed on experiments with free banking, can be located in Rome in the year 33 AD". He also points out Keynes's work (1936) which discusses the importance of the banking sector in economic growth. See also Fry (1995).

Note 2. For further details see for instance, Ang and Mckibbin (2007).

Note 3. FSR is the ratio between the total assets of financial institution divided by GDP. Levine and Zervos (1998), Levine (1998) and Nili and Rastad (2007) used this indicator.

Note 4. The mix results among variable indicate that variables considered in our model are integrated of different order, which means that variables are integrated of being $\mathrm{I}(0)$ or $\mathrm{I}(1)$. However, to compare the differences of conventional and innovative co-integration tests in spite of the noticeably inconsistent results of I(0) and I(1), we first apply Engle and Granger (1987) and Johansen and Juselius (1990) techniques to test for the long-run equilibrium relationship among variables in our finance-growth model, then we use ARDL approach, see Nieh and Wang (2005). As a result, the hypothesis of no co-integration between financial development and economic growth was also rejected by Engle \& Granger (1987) and Johansen and Juselius (1990).

Note 5. All information criteria result in similar results.

\section{Appendix A. Description and Source of Data}

\begin{tabular}{|c|c|c|c|}
\hline Variable & Proxy & Description & Source \\
\hline \multicolumn{4}{|l|}{ Dependent variables } \\
\hline \multicolumn{4}{|l|}{ Economic Growth indicator: } \\
\hline $\begin{array}{l}\text { Real Gross domestic product per } \\
\text { capita. }\end{array}$ & RGDPPC & $\begin{array}{l}\text { Real gross domestic product divided by population. It } \\
\text { is used as a measure of economic growth. }\end{array}$ & SAMA \\
\hline \multicolumn{4}{|l|}{ Independent Variables } \\
\hline & & Bank deposits are calculated by taking the difference & \\
\hline Bank deposits liabilities over GDP & BDR & between total bank deposits liabilities minus currency & \\
\hline & & outside the banks divided by GDP. & \\
\hline \multirow{6}{*}{ Credit to private sector over GDP } & & Total domestic credits made by commercial banks & \\
\hline & CPS & and other deposit-taking bank to the private sector. It & \\
\hline & & is expected a positive effect on dependent variable. & \\
\hline & & Financial savings are calculated by difference & \\
\hline & & between M3 and M1 (FS=M3-M1) divided by GDP. & \\
\hline & & & SAMA \\
\hline \multicolumn{4}{|l|}{ Financial savings over GDP } \\
\hline & FSR & & \\
\hline Investment as a ratio of GDP & INVR & & Central Dep. Of Statistics \\
\hline Trade Openness over GDP & OPEN & $\begin{array}{l}\text { Actual trade flows such as Imports plus exports as a } \\
\text { percentage of GDP. }\end{array}$ & $\begin{array}{l}\& \text { information, Ministry } \\
\text { of Economy and Planning }\end{array}$ \\
\hline
\end{tabular}

\section{Copyrights}

Copyright for this article is retained by the author(s), with first publication rights granted to the journal.

This is an open-access article distributed under the terms and conditions of the Creative Commons Attribution license (http://creativecommons.org/licenses/by/3.0/). 